\title{
THE REVIEW OF INDIAN CAPITAL MARKET
}

\author{
Dr. Rajagopalan Usha
}

Assistant Professor, Prince sultan university, Riyadh, Saudi Arabia

\begin{abstract}
The capital market is an important constituent of the financial system. It is a market for long term funds both equity and debt. It mainly deals with financial assets, excluding coin and currency; the financial assets comprise shares, debentures, bonds, mutual funds, fixed deposits, pension funds, provident fund, insurance policies, and derivatives. The Indian Stock Exchanges, as they are well-regulated, function smoothly, and it is an indication of healthy capital market. Stock exchange provides a good leverage to the capital market and it helps women investors to maximize their returns. This article clearly deprives the review of Indian Capital Market.
\end{abstract}

Key words: Financial assets, Economic Policies, East India Company, Mumbai Stock economic policies, Regional and National Stock Exchanges.

Cite this Article: Rajagopalan Usha, The Review of Indian Capital Market, International Journal of Management, 11(12), 2020, pp. 3062 -3084.

http://iaeme.com/Home/issue/IJM?Volume=11\&Issue $=12$

\section{INTRODUCTION}

India has multi-stock exchange system. Regional and National Stock Exchanges (NSE) are functioning across the country. The political changes in the country and the economic policies of the Government affect the trends of capital market.

\subsection{History of Indian Capital Market}

The history of the capital market in India dates back to the eighteenth century when East India Company securities traded in the country. Until the end of the nineteenth century, securities trading were unorganized and the main trading centers were Bombay and Calcutta (Bombay named Mumbai and Calcutta named Kolkata). Of the two, Mumbai was the chief trading center wherein bank shares were the major trading stock. Mumbai Stock Exchange (BSE) was recognized in May 1927 under the Mumbai Securities Contract Control, 1925. In the 1950s, Century Textiles, Tata Steel, Bombay Dyeing, National Rayon, and Kohinoor Mills were the favourite scripts of speculators.

In the 1970s, Badla trading was resumed under the disguised form of hand-delivery contracts to revive the capital market. However, the capital market received another severe setback on $6^{\text {th }}$ July 1974, when the Government promulgated the dividend restriction ordinance. The 1980s witnessed an explosive growth of securities market in India. The decade of 1980s 
was characterized by an increase in the number of stock exchanges, listed companies, and paidup capital and market capitalization. The 1990s were the most important decade in the history of capital market of India. Liberalization, globalization and privatization were the new concepts that swept through the Indian economy. This has resulted in emergence of Securities Exchange of Board of India (SEBI) as a regulator of capital market. SEBI was established with the objective of protecting women investors through regulations.

\section{STATEMENT OF THE PROBLEM}

Attitudes are the feelings and beliefs that largely determine how women will perceive their environment, commit themselves to intended actions and ultimately take their investment decision. Attitude form a mental set up that affects how the women investors view things

The present education system, books, the media and all other prevailing socio-cultural norms exhibit the image of women as best investors with ingenious knowledge about returns. Women investors themselves are so conditioned that they too unquestioningly accept this view of themselves and criticize other woman who might choose to step out of this traditional acceptable and pliable mould of investment.

In 1991, the Indian Government initiated a comprehensive market-oriented reform programme. The core point was a phased deregulation of the financial sector along with reforms of trade and industrial policies. Important elements of the financial liberalization program was a lifting of several interest rate ceilings in both credit and bond markets, easing of requirements that had made it mandatory for banks to hold a part of their portfolio in noninterest-bearing reserves and low-yielding government securities, a partial dismantling of barriers to enter into the banking sector and greater freedom given to banks to close unviable branches in rural and semi-urban areas. Along with the liberalization measures, there was a move to introduce a regulatory mechanism that could ensure safety and solvency of financial sector in the deregulated environment. Measures initiated in the past in the Indian economy by the Government through devaluation, deregulation, delicencing, globalization, capital market reforms, and free pricing have further increased the interest in stock market. A number of new women investors and significant fresh funds have been introduced in the market.In addition, the Government is also keen to attract foreign investment in Indian Capital Market through a number of stock exchanges, membership, number of listed companies, women investors' population, primary market, new institutions and instruments. The above argument profoundly forces the researcher to study the implications of financial sector reforms especially in the Indian Capital Market. It is also pertinent to study how the capital market reforms accelerate the growth of the industry and help the women investors regarding awareness and transparency

\section{NEED AND IMPORTANCE OF THE STUDY}

When women move forward, the family moves, the village moves and the nation moves" are the words of Pandit Jawaharlal Nehru. According to his words, women are marching forward in the country's work force and are contributing towards the development of their family, their organisation and thereby for the development of our economy. Since independence, the improvement in the educational system for girls, globalization, economic development etc., has led to more and more women entering into the share market. The economic condition, a desire of self fulfillment, a sense of devaluation of the domestic role, a desire to have an economic independence etc., drive the women to take active participation in the country's work force. Modern women have made it big in different fields and opened the door to many opportunities that were closed to them in the past.

The New Economic Policy (NEP) of structural adjustment and stabilization programme was given a big thrust in India in June 1991.The financial sector reforms received special attention 
as a part of this policy because of the perceived interdependent relationship between the real and financial sectors of the modern economy. Immediately after the announcement of NEP, the Government appointed a high level committee of financial system under the chairmanship of Narashiman, "to examine all aspects relating to the structure, organization, functions and procedures of the financial system". The committee submitted its main report in November 1991. Since then, the authorities introduced a large number of reforms in the Indian financial sector in the light of the said report.

\section{OBJECTIVES OF THE STUDY}

Based on the above observations, facts, and information this study has been undertaken with the following specific research objectives:

- To study the various changing scenarios in capital market and its influence on investment preference,

- To observe the behaviour of women investors and to their investment preferences.

- To analyse the enhanced awareness of the women investors with regard to the latest developments in the capital market after 1991 and to assess and predict the extent of return on investment.

- To ascertain the sources of information leading the women investors to select the industry for right investment.

- To examine the impact of personal demographic variables of women investors on capital market reforms and investments.

- To suggest the agencies about problems faced by women investors and to evolve appropriate strategies for enhancing investment decisions.

\subsection{Growth of Indian Capital Market}

The Indian Capital Market has seen many ups and downs in the last three decades both in terms of amounts mobilized in primary market and market capitalization of the secondary market. The equity cult, too, has spread far and wide with a number of investing public raising to around 30 millions. It has been estimated that 35 lakh new women investors are added each year (Sanjeev Agarwal, 2001). There has been a shift of household savings from physical assets to financial assets, particularly to risk bearing securities such as shares and debentures. The growth of volume in primary and secondary markets has been tremendous in recent years. The number of public issues and the level of subscriptions evince the interest of women investors.

\subsection{Financial Sector Reforms}

The need for financial reforms has arisen because the financial institutions and markets were in a bad shape. The banking sector suffered from lack of competition, low capital base, low productivity and high intermediation costs. The role of technology was minimal, and the quality of service was abysmal. Proper risk management system was not followed, and prudential norms were weak. Developmental financial institutions operated in a over-protected environment with most of the funding coming from assured sources. Financial markets were characterized by control over pricing of financial assets, barriers to entry, and high transaction costs. The banks were running either at a loss or on very low profits, and, consequently were unable to provide adequately for loan defaults, and build their capital. There had been organizational inadequacies, weakening of management and control functions, the growth of restrictive practices, the erosion of work culture, and flaws in credit management. The financial sector reforms have been operating in conjunction with a larger set of goals relating to economic stability and growth. The reforms which have been introduced at a gradual pace combines with 
effective and appropriate regulation and intervention policy. Efforts have also been made to fulfill the "commandments" of financial sector reforms, namely, carrying out a macroeconomic stabilization programme, introducing supportive fiscal and external sector policies, and implementing wide-ranging reforms in other sectors simultaneously.

\subsection{Objectives of Financial Reforms Introduced in 1991}

The main objectives of financial reforms are:

- To develop a market oriented, competitive, world-integrated, diversified autonomous transparent financial system

- To increase the allocative efficiency of available savings, and to promote accelerated growth of the real sector

- To increase the rate of return on real investment

- To promote competition by creating level-playing fields and facilitating free entry and exit for institutions and market players

- To reduce the levels of resource pre-emption and to improve the effectiveness of directed credit programs

- To build a financial infrastructure relating to supervision, audit, technology, and legal matters

- To modernize the instruments of monetary control so as to make them more suitable for the conduct of monetary policy in a market economy i.e., to increase the reliance on indirect or market - incentive based instruments rather than direct or physical instruments of monetary control

- To increase effectiveness, accountability, profitability, viability, vibrancy, balanced growth, operational economy and flexibility, with professionalizing and depoliticisation in the financial sector.

\subsection{Major Reforms After 1991}

The reforms have had a broad sweep comprising operational matters, banking, primary and secondary stock markets, Government securities market, external sector policies. They have been classified into three areas: issues relating to creating a resilient banking system; secondly development of institutions such as private sector banks and mutual funds; and thirdly, monetary policy instruments such as interest rates, reserve ratios, and refinancing facilities. While presenting a list of reforms, it needs to be pointed out that sometimes a distinction between normal policy changes which are specific in time and economic conditions and reforms proper are not maintained; the former are included in the latter, which makes the list of reforms unduly and unmanageably long. It is primarily in this sense that the major reforms are listed in terms of certain categories - systematic and policy reforms, banking reforms, primary and secondary stock market reforms, government securities market reforms, external financial market reforms.

\subsection{Classification of Capital Market}

The capital market comprises two types of sectors namely

- Primary market and

- Secondary market. 


\subsubsection{Primary Market}

Primary market refers to the long-term flow of funds from the surplus sector to the government and corporate sector, and to banking and non-banking financial intermediaries. Primary issues of the corporate sectors lead to capital formation. The fund raising of the primary market is done in three ways namely, domestic, external, and other external borrowings. In domestic fund raising - issue of equity, debenture instruments, financial intermediaries and Government Bonds and Securities play a significant role. The external fund raising is achieved through Global Depositary Receipts (GDRs). Other external borrowings such as Foreign Direct Investments (FDI) and Non-Resident Indians deposit (NRIs) also contribute towards raising funds in primary market Table 1 indicates the resources mobilized through public issues

Table 1 Resource Mobilisation from the Primary Market

\begin{tabular}{|c|c|c|c|c|c|c|c|c|c|c|}
\hline Issues & $\begin{array}{c}\text { 1995- } \\
96\end{array}$ & $\begin{array}{c}\text { 1996- } \\
97\end{array}$ & 1997-98 & 1998-99 & 1999-00 & 2000-01 & 2001-02 & 2002-03 & 2003-04 & 2004-05 \\
\hline $\begin{array}{l}\text { Corporate } \\
\text { Securities }\end{array}$ & 366,890 & 371,470 & 421,250 & 601,920 & 724,500 & 783,956 & 744,032 & 752,411 & 748,500 & $1,092,970$ \\
\hline $\begin{array}{l}\text { Domestic } \\
\text { Issues }\end{array}$ & 361,930 & 338,720 & 377,380 & 590,440 & 689,630 & 741,986 & 720,612 & 718,147 & 717,520 & $1,059,440$ \\
\hline \begin{tabular}{|c|} 
Non-Govt. \\
Public \\
Companies \\
\end{tabular} & 160,750 & 104,100 & 31,380 & 50,130 & 51,530 & 48,900 & 56,920 & 18,777 & 36,750 & 134,820 \\
\hline PSU Bonds & 22,920 & 33,940 & 29,820 & -- & -- & -- & -- & -- & -- & -- \\
\hline $\begin{array}{c}\text { Govt. } \\
\text { Companies } \\
\end{array}$ & 10,000 & 6500 & 430 & -- & -- & -- & 3,500 & -- & 1,000 & 26,840 \\
\hline Banks \& FIs & 34,650 & 43,520 & 14,760 & 43,520 & 25,510 & 14,720 & 10,700 & 29890 & 40,760 & 57,260 \\
\hline $\begin{array}{c}\text { Private } \\
\text { Placement }\end{array}$ & 133,610 & 150,660 & 300,990 & 496,790 & 612,590 & 678,360 & 649,500 & 669,480 & 639,010 & 840,520 \\
\hline Euro Issues & 12,970 & 55,940 & 40,090 & 11,480 & 34,870 & 41,970 & 23,420 & 34,264 & 30,980 & 33,530 \\
\hline \begin{tabular}{|c|} 
Government \\
Securities \\
\end{tabular} & 467,830 & 426,880 & 673,860 & $1,060,670$ & $, 133,360$ & $1,284,830$ & $1,525,080$ & $1,819,790$ & $1,981,570$ & $1,456,020$ \\
\hline $\begin{array}{c}\text { Central } \\
\text { Government }\end{array}$ & 405,090 & 361,520 & 596,370 & 939,530 & 996,300 & $1,151,830$ & $1,338,010$ & $1,511,260$ & $1,476,360$ & $1,065,010$ \\
\hline \begin{tabular}{c|} 
State \\
Governments \\
\end{tabular} & 62,740 & 65,360 & 77,490 & 121,140 & 137,060 & 133,000 & 187,070 & 308,530 & 505,210 & 391,010 \\
\hline Total & 834,720 & 798,350 & $1,095,110$ & $1,662,590$ & $1,857,860$ & $2,068,786$ & $2,269,112$ & $2,572,201$ & $2,730,070$ & $2,548,990$ \\
\hline
\end{tabular}

Source: RBI Annual Report

It is observed from the table that an aggregate of Rs. 2,548,990 millions have been raised by the government and the corporate sector during 2004-05 as against Rs. 2,730,070 million during the preceding year. The state and central Governments have raised about two thirds of the total resources, with the central government alone raising nearly Rs.1,065,010 million.

The average annual capital mobilisation from the primary market has grown manifold since the last two-three decades. Data in table 1.1 shows that there is a high preference for raising resources in the primary market through private placement route. Private placements accounted for $76 \%$ of total resources mobilized through domestic issues by corporate sector during 200405 .

As may be seen from the table 1.1, Indian market is getting integrated with the global market, though in a limited way through Euro Issues. Since they are permitted in accessing in 
1992, Indian companies have raised about Rs. 33,530 millions through American Depository Receipts (ADRs)/Global Depository Receipts (GDRs).

Foreign Institutional Women investors (FIIs) invested heavily in Indian market Foreign Institutional Women investors (FIIs) invested heavily in Indian market in 2004-05. They had a net cumulative investment of US\$ 35.93 billions as at end of March 2005. There were 685 FIIs registered with Security Exchange Board of India (SEBI) at the end of March 2005.

It appears that more and more people prefer mutual funds (MFs) as their investment vehicle. This change in investor behavior is induced by the evolution of a regulatory framework for MFs, tax concessions offered by government and preference of women investors for passive investing. Starting with an asset base of Rs. 250 millions in 1964, the total assets under management at the end of March 2004 rose to Rs. 1,495,540 million. During the last one decade, the resources mobilized by the MFs increased from Rs. 112,440 million in 1993-94 to Rs. 468,090 million in 2004-05.

\subsubsection{Government Securities}

The primary issues of the Central Government have increased manifold during the decade of 1990s from Rs. 89,890 million in 1990-91 to Rs. 1,476,360 million in 2003-04. However, it witnessed a slight dip in the year 2004-05 to Rs. 1,065,010 million (ISMR, 2005). The issues by state governments have also increased from Rs. 25,690 millions in 1990-91 to Rs. 505,210 million in 2003-04, but the same trend was witnessed in the case of government securities followed in the State governments too, wherein they raised Rs. 391,010 millions in 2004-05. The Central Government mobilised Rs. 803,500 millions through the issues of dated securities and Rs. 261,510 million through the issues of Treasury Bill (T-bills). After meeting repayment liabilities of Rs. 343,160 million for dated securities, and redemption of T-bills of Rs. 261,360 million, net market borrowing of Central Government stood at Rs. 460,500 million for the year 2004-05. The state governments collectively raised Rs. 391,010 million during 2004-05 as against Rs. 505,210 million in the preceding year. The net borrowings of State Governments in 2004-05 amounted to Rs. 339,780 million.

Along with the growth of the market, the investor base has also widened. In addition to banks and insurance companies, corporates and individual women investors are also investing in government securities. The weighted average cost of its borrowing have increased to $6.11 \%$ in 2004-05. The maturity structure of government debt is also changing. About $77 \%$ of primary issues have been raised through securities with maturities above 5 years and upto 10 years. As a result, the weighted average maturity of dated securities increased to 14.13 years in 2004-05 (ISMR, 2005).

\subsubsection{Secondary Market}

Secondary Market is a market for outstanding securities. An equity instrument, being an external fund, provides an all-time market while a debt instrument with a defined maturity period is traded at the secondary market till maturity. It facilitates only liquidity and marketability of outstanding debt and equity instruments. The secondary market contributes to the economic growth by channelising funds into the most efficient channels through the process of disinvestments to reinvestment. It also provides instant valuation of securities made possible by changes in the internal environment, that is, through companywide and industry wide factors. This valuation helps the measurement of the cost of capital and rate of return of economic entities at the micro level. Indian Capital Market has two dimensions, namely,

- Secondary market for corporate, and financial intermediaries

- Secondary market for government securities and public sector undertaking bonds. 
The corporate and financial intermediaries are in the form of recognized stock exchanges, namely, National Stock Exchange (NSE), Over the Counter Exchange of India Limited (OTCEI), and Inter Connected Stock Exchange of India. The secondary market transaction in Government securities are conducted through the subsidiary general ledger, Whole Sale Debt Market (WDM) of the National Stock Exchange, Mumbai Stock Exchange (BSE), and Over the Counter Exchange of India Limited.

\section{AN OVERVIEW ABOUT EXCHANGES IN INDIA}

Exchanges in India offer screen based, electronic trading. The trading system is connected using the Very Small Aperture Terminal (VSAT) technology from around 345 cities. There were 9,128 trading members registered with SEBI at end of March 2005 (Table 1.2).

The market capitalization has grown over the period indicating more companies using the trading platform of the stock exchange. The all India market capitalization is estimated at Rs. $16,984,280$ million at the end of March 2005. The market capitalization ratio defined as the value of listed stocks divided by Gross Domestic Product (GDP) is issued as a measure of stock market size. It is of economic significance since market is positively correlated with the ability to mobilize capital and diversify risk. It increased sharply to $119.1 \%$ in $2004-05$ against $52.3 \%$ in the previous year.

The trading volumes on exchanges have been witnessing a phenomenal growth over the past decade. The trading volume, which peaked atRs. 28,809,900 million in 2000-01, fell substantially to Rs. 9,689,098 million in 2002-03. However, the year 2004-05 maintained its trading volume when compared to the previous year. The trading volume for the fiscal 2004-05 stood at 16,668,960 million. The turnover ratio, which reflects the volume of trading in relation to the size of the market, stood at $98.1 \%$ for the year 2004-05.

The relative importance of various stock exchanges in the market has undergone dramatic change during this decade. The increase in turnover took place mostly at the big exchanges. The NSE yet again registered as the market leader with more than $89 \%$ of total turnover (volumes on all segments) in 2004-05. Top 5 stock exchanges accounted for $99.9 \%$ of turnover, while the rest 18 exchange had negligible volumes during 2004-05 (Table 1.3).

Table 2 Secondary Market - Selected Indicators (Amount in Rs. mn.)

\begin{tabular}{|c|c|c|c|c|c|c|c|c|c|c|c|}
\hline \multirow{3}{*}{$\begin{array}{c}\text { At the } \\
\text { End of } \\
\text { Financial } \\
\text { Year }\end{array}$} & \multicolumn{8}{|c|}{ Capital Market Segment of Stock Exchanges } & \multirow{2}{*}{\multicolumn{2}{|c|}{$\begin{array}{l}\text { Turnover of Non- } \\
\text { Repo Government } \\
\text { Securities }\end{array}$}} & \multirow{3}{*}{$\begin{array}{l}\begin{array}{c}\text { Turnover } \\
\text { of }\end{array} \\
\text { Derivatives } \\
\text { Segment of } \\
\text { Exchanges }\end{array}$} \\
\hline & \multirow{2}{*}{\begin{tabular}{|l|} 
No. of \\
Brokers
\end{tabular}} & \multirow{2}{*}{\begin{tabular}{|c|} 
No. of \\
Listed \\
Companies
\end{tabular}} & \multirow{2}{*}{$\begin{array}{l}\text { S\&P } \\
\text { CNX } \\
\text { Nifty }\end{array}$} & \multirow[b]{2}{*}{ Sensex } & \multirow{2}{*}{$\begin{array}{c}\text { Market } \\
\text { Capitali- } \\
\text { sation }\end{array}$} & \multirow{2}{*}{$\begin{array}{c}\text { Market } \\
\text { Capitali- } \\
\text { sation } \\
\text { Ratio } \\
\text { (\%) }\end{array}$} & \multirow[b]{2}{*}{ Turnover } & \multirow{2}{*}{$\begin{array}{l}\text { Turnover } \\
\text { Ratio(\%) }\end{array}$} & & & \\
\hline & & & & & & & & & $\begin{array}{c}\text { On WDM } \\
\text { Segment } \\
\text { of NSE }\end{array}$ & On SGL & \\
\hline $1995-96$ & 8,476 & 9,100 & 985.30 & 3366.61 & $5,722,570$ & 47.0 & $2,273,680$ & 39.7 & 92,433 & 295,300 & -- \\
\hline $1996-97$ & 8,867 & 9,890 & 968.85 & 3360.89 & $4,883,320$ & 34.6 & $6,461,160$ & 132.3 & 381,023 & 939,210 & -- \\
\hline $1997-98$ & 9,005 & 9,833 & 1116.65 & 3892.75 & $5,898,160$ & 37.7 & $9,086,810$ & 154.1 & 975,152 & $1,610,900$ & -- \\
\hline $1998-99$ & 9,069 & 9,877 & 1078.05 & 3739.96 & $5,740,640$ & 34.1 & $10,233,820$ & 178.3 & 904,158 & $1,875,310$ & -- \\
\hline 1999-00 & 9,192 & 9,871 & 1528.45 & 5001.28 & $11,926,300$ & 84.7 & $20,670,310$ & 173.3 & $2,915,915$ & $4,564,910$ & -- \\
\hline $2000-01$ & 9,782 & 9,954 & 1148.20 & 3604.38 & $7,688,630$ & 54.5 & $28,809,900$ & 374.7 & $4,124,958$ & $5,721,456$ & 40,180 \\
\hline
\end{tabular}


The Review of Indian Capital Market

\begin{tabular}{|l|l|l|l|l|l|l|l|l|l|l|l|}
\hline $2001-02$ & 9,687 & 9,644 & 1129.55 & 3469.35 & $7,492,480$ & 36.4 & $8,958,180$ & 119.6 & $9,269,955$ & $12,119,658$ & $1,038,480$ \\
\hline $2002-03$ & 9,519 & 9,413 & 978.20 & 3048.72 & $6,319,212$ & 28.5 & $9,689,098$ & 153.3 & $10,305,497$ & $13,923,834$ & $4,423,333$ \\
\hline $2003-04$ & 9,368 & -- & 1771.90 & 5590.60 & $13,187,953$ & 52.3 & $16,204,977$ & 122.9 & $12,741,190$ & $17,013,632$ & $21,422,690$ \\
\hline $2004-05$ & 9,128 & -- & 2035.65 & 6492.82 & $16,984,280$ & 119.1 & $16,668,963$ & 98.1 & $8,493,250$ & $12,608,667$ & $25,641,269$ \\
\hline
\end{tabular}

Note: Turnover figures for the respective year Not Available.

Table 3 Growth and Distribution of Turnover on Stock Exchanges (Rs. mn.)

\begin{tabular}{|c|c|c|c|c|c|c|c|c|c|c|c|}
\hline SI. No. & $\begin{array}{c}\begin{array}{c}\text { Stock } \\
\text { Exchanges }\end{array} \\
\end{array}$ & 1995-96 & 1996-97 & 1997-98 & 1998-99 & 1999-00 & 2000-01 & 2001-02 & 2002-03 & 2003-04 & 2004-05 \\
\hline 1 & NSE & 800,090 & $3,367,820 \mathrm{~s}$ & $4,811,970$ & $5,198,520$ & $11,32,680$ & $17,704,580$ & $15,622,830$ & $21,265,445$ & $45,462,793$ & $45,744,186$ \\
\hline 2 & Mumbai & 500,640 & $1,242,840$ & $2,073,830$ & $3,119,990$ & \multicolumn{2}{|c|}{$6,850,28210,016,190$} & $3,093,156$ & $3,165,516$ & $5,146,730$ & $5,357,913$ \\
\hline 3 & Calcutta & 621,280 & $1,056,640$ & $1,787,780$ & $1,717,804$ & $3,571,655$ & $3,550,354$ & 270,747 & 65,399 & 19,275 & 27,150 \\
\hline 4 & Delhi & 100,760 & 486,310 & 678,400 & 517,593 & 932,889 & 838,711 & 58,280 & 111 & 34 & \\
\hline 5 & Ahmedabad & 87,860 & 205,330 & 307,710 & 297,342 & 375,656 & 540,352 & 148,435 & 154,586 & 45,445 & 80 \\
\hline 6 & $\begin{array}{c}\text { Uttar } \\
\text { Pradesh. }\end{array}$ & 23,730 & 160,700 & 153,900 & 186,267 & 240,478 & 247,467 & 252,373 & 147,634 & 117,510 & 53,430 \\
\hline 7 & Ludhiana & 48,490 & 52,740 & 83,150 & 59,779 & 77,405 & 97,322 & 8,566 & 0 & 0 & \\
\hline 8 & Pune & 70,710 & 99,030 & 86,240 & 74,528 & 60,868 & 61,705 & 11,710 & 18 & 0 & 3 \\
\hline 9 & Bangalore & 8,900 & 43,980 & 86,360 & 67,790 & 111,474 & 60,328 & 703 & 0 & 1 & \\
\hline 10 & Hyderabad & 12,850 & 4,800 & 18,600 & 12,759 & 1365 & 9,778 & 413 & 46 & 20 & 140 \\
\hline 11 & 1CSE & & & & 7 & 5,452 & 2,331 & 554 & 648 & 1 & \\
\hline 12 & Co chin & 18,030 & 14,010 & 17,830 & 7,730 & 0 & 1,866 & 0 & 0 & 0 & \\
\hline 13 & OCTEl & 2,180 & 2,210 & 1,250 & 1,422 & 35,879 & 1,259 & 38 & 1 & 158 & \\
\hline 14 & Madras & & 23,150 & 12,280 & 3,696 & 2,502 & 1,092 & 241 & 0 & 1,009 & 270 \\
\hline 15 & $\begin{array}{l}\text { Madhya } \\
\text { Pradesh }\end{array}$ & 2,040 & c 120 & 10 & 9 & 97 & 24 & 235 & 0 & 0 & \\
\hline 16 & Magadh & 16,290 & 27,550 & 3,230 & 0 & 80 & 16 & 0 & 5 & 1 & \\
\hline 17 & Vadodara & 12,590 & 42,680 & 45,760 & 17,491 & 1,593 & 9 & 101 & 25 & 1 & \\
\hline 18 & Gauhati & 6,190 & 4,840 & 200 & 302 & 0 & 0 & 1 & 1 & 0 & \\
\hline 19 & $\begin{array}{c}\text { Bhubanesh } \\
\text { war }\end{array}$ & 2,260 & 2,310 & 2,020 & 770 & 701 & 0 & 0 & 0 & 0 & \\
\hline 20 & Coimbatore & 25,030 & 23,980 & 21,360 & 3,947 & 388 & 0 & 266 & 0 & 0 & \\
\hline 21 & Jaipur & 10,470 & 15,190 & 4,310 & 648 & 21 & 0 & 0 & 0 & 0 & \\
\hline 22 & Mangalore & 390 & 3,730 & 3,080 & 112 & 1 & 0 & 0 & 0 & 0 & 0 \\
\hline 23 & SKSE & 5,640 & 3,980 & 170 & 0 & 0 & 0 & 0 & 0 & 0 & 0 \\
\hline & Total & $2,376,420$ & $6,83,940$ & $10,199,440$ & $11,288,506$ & $23,712,466$ & $33,133,385$ & $19,468,650$ & $24,799,434$ & $50,792,977$ & $51,183,172$ \\
\hline
\end{tabular}

Note: Turnover means total value of transactions of securities in all market segments of an Exchange. For NSE, all three segments viz., CM, F\&O and WDM and BSE, two segments viz., CM and F\&O are included.Source: NSE Fact Book 2005 


\subsection{Government Securities}

The trading in non-repo government securities declined marginally in the year 2004-05 as compared to the previous year. The aggregate trading volumes in non-repo central and state government dated securities on Subsidiary General Ledger (SGL) declined from Rs. 17,013,632 million in 2003-04 to Rs. 12,608,667 million in 2004-05 (NSE Fact Book 2005). The share of Wholesale Debt Market (WDM) segment of NSE in the total of Non-repo government securities decreased marginally from $74.89 \%$ 'in $2003-04$ to $67.36 \%$ in $2004-05$.

\subsection{Dependence on Securities Market}

\subsubsection{Corporate Sector}

The 1990s witnessed the emergence of the securities market as a major source of finance for trade and industry in India. A growing number of companies have been accessing the securities market rather than depending on loans from financial institutions (FIs)/banks. The corporate sector is increasingly depending on external sources (domestic market borrowings and loans) for meeting its funding requirements. According to the data released by the Centre for Monitoring Indian Economy (CMIE) data (Table 1.4), the share of capital market based instruments had been quite significant in the 1990s, however, it declined to $20.60 \%$ in 2001 02. But the year 2002-03 witnessed the erosion of the corporates to raise money from capital market, which was mainly because of the subdued conditions prevalent in the primary and secondary markets.

Table 4 Dependence on Securities Market

\begin{tabular}{|c|c|c|c|c|}
\hline \multirow{2}{*}{ Year } & \multicolumn{4}{|c|}{ Share (\%) of Securities Market in } \\
\cline { 2 - 5 } & $\begin{array}{c}\text { External Finance } \\
\text { of Corporates }\end{array}$ & $\begin{array}{c}\text { Fiscal Deficit of } \\
\text { Central } \\
\text { Government }\end{array}$ & $\begin{array}{c}\text { Fiscal Deficit of } \\
\text { State Government }\end{array}$ & $\begin{array}{c}\text { Financial Savings } \\
\text { of Households }\end{array}$ \\
\hline $1995-96$ & 21.67 & 54.9 & 18.7 & 7.7 \\
\hline $1996-97$ & 22.12 & 30.0 & 17.5 & 6.9 \\
\hline $1997-98$ & 28.16 & 36.5 & 16.5 & 4.5 \\
\hline $1998-99$ & 27.05 & 60.9 & 14.1 & 4.2 \\
\hline $1999-00$ & 33.58 & 67.1 & 13.9 & 7.3 \\
\hline $2000-01$ & 31.39 & 64.4 & 13.8 & 4.3 \\
\hline $2002-03$ & $(17.98)$ & 77.6 & 19.9 & 10.3 \\
\hline $2003-04$ & N.A. & 64.9 & 38.6 & 11.4 \\
\hline $2004-05$ & N.A. & 65.8 & 27.3 & N.A. \\
\hline
\end{tabular}

Source: CMIE \& RBI Annual Report

Table 1.5 presents sector-wise shareholding pattern of companies listed on NSE. It is observed that on an average the promoters hold more than $58.43 \%$ of total shares. Though the non-promoter holding is about $41.57 \%$, the public held only $15.52 \%$ and the institutional holdings (by FIIs, MFs, FIs) accounted for $16.15 \%$. There is not much significant difference in the shareholding pattern of companies in different sectors. About $57.64 \%$ of shares in companies in Petrochemicals sector are held by Indian promotersable 1.5 Shareholding Pattern at the end of March 2005 of Companies Listed on NSE 
Table 5 (In per cent)

\begin{tabular}{|c|c|c|c|c|c|c|c|c|c|c|}
\hline \multirow{3}{*}{ Sectors } & \multicolumn{7}{|c|}{ Non-Pomoters' Holding } & \multirow{2}{*}{\multicolumn{3}{|c|}{ Promoters' Holding }} \\
\hline & \multicolumn{3}{|c|}{$\begin{array}{c}\text { Institutional Women } \\
\text { investors }\end{array}$} & \multicolumn{4}{|c|}{$\begin{array}{c}\text { Non - Institutional Women } \\
\text { investors }\end{array}$} & & & \\
\hline & $\begin{array}{l}\text { FIs/Banks/ } \\
\text { Insurance } \\
\text { Companies }\end{array}$ & FIls & $\begin{array}{l}\text { MFs } \\
\& \\
\text { UTI }\end{array}$ & $\begin{array}{l}\text { Indian } \\
\text { Public }\end{array}$ & $\begin{array}{l}\text { NRIs/ } \\
\text { OCBs }\end{array}$ & $\begin{array}{l}\text { Private } \\
\text { Corporate } \\
\text { Bodies }\end{array}$ & Others & $\begin{array}{c}\text { Indian } \\
\text { Promoters }\end{array}$ & $\begin{array}{c}\text { Foreign } \\
\text { Promo-ters }\end{array}$ & $\begin{array}{c}\text { Persons } \\
\text { Acting in } \\
\text { concert }\end{array}$ \\
\hline Finance & 7.18 & 13.54 & 1.79 & 18.45 & 1.06 & 4.93 & 4.39 & 44.33 & 0.91 & 3.40 \\
\hline FMCG & 10.64 & 11.91 & 0.90 & 19.85 & 0.50 & 1.70 & 0.14 & 13.32 & 40.83 & 0.23 \\
\hline Infrastructure & 1.50 & 6.25 & 0.47 & 4.09 & 0.31 & 1.45 & 0.71 & 84.93 & 0.20 & 0.10 \\
\hline $\begin{array}{l}\text { Information } \\
\text { Technology }\end{array}$ & 2.51 & 10.66 & 1.86 & 23.99 & 1.34 & 12.28 & 5.07 & 38.33 & 1.70 & 2.27 \\
\hline Manufacturing & 6.70 & 7.27 & 2.83 & 14.60 & 1.06 & 4.59 & 2.89 & 48.84 & 7.64 & 3.59 \\
\hline $\begin{array}{c}\text { Media \& } \\
\text { Entertainment }\end{array}$ & 2.87 & 13.89 & 3.24 & 26.12 & 1.14 & 8.70 & 1.92 & 34.60 & 7.02 & 0.51 \\
\hline Petrochemicals & 4.47 & 3.45 & 1.34 & 16.34 & 1.61 & 4.09 & 7.86 & 57.64 & 0.97 & 2.23 \\
\hline $\begin{array}{c}\text { Pharmaceutical } \\
\text { s }\end{array}$ & 3.76 & 9.61 & 2.04 & 21.92 & 2.18 & 5.03 & 2.97 & 43.10 & 6.72 & 2.66 \\
\hline Services & 8.16 & 7.20 & 2.68 & 17.78 & $I ; D 8$ & 4.63 & 2.39 & 46.78 & 7.50 & 1.79 \\
\hline $\begin{array}{c}\text { Telecommunic } \\
\text { ation }\end{array}$ & 4.42 & 17.06 & 1.42 & 5.76 & $\begin{array}{c}13.8 \\
4\end{array}$ & 2.73 & 1.68 & 48.54 & 3.68 & 0.88 \\
\hline Miscellaneous & 9.55 & 4.18 & 3.25 & 21.18 & 2.17 & 8.33 & 3.92 & 36.79 & 5.95 & 4.68 \\
\hline All Companies & 5.66 & 8.48 & 2.01 & 15.52 & 1.66 & 4.78 & 3.46 & 50.24 & 5.63 & 2.56 \\
\hline
\end{tabular}

Source: RBI Annual Report

\subsection{Governments}

Due to the increase in fiscal deficits of the governments, their dependence on market borrowings to finance fiscal deficits has also increased over the years. During the year 199091, the state governments and the central government financed nearly $14 \%$ and $18 \%$, respectively, of their fiscal deficit by market borrowing. In percentage terms, dependence of the state governments on market borrowing did not increase much during the decade as it ranged between $13.8 \%$ and $23, .0 \%$. In 2004-05, the state and the central government market borrowings financed $27.3 \%$ and $65.8 \%$ of the fiscal deficit respectively (ISMR, 2005).

\subsection{Households}

According to the RBI data, household sector accounted for $84.7 \%$ of gross domestic savings during 2003-04. However, this increased to $84.8 \%$ in 2004-05. In the last fiscal 2004-05, they invested $39.4 \%$ of financial savings in deposits, $26.4 \%$ in insurance/provident funds, $19.0 \%$ on small savings, and $6.1 \%$ in securities (out of which the investment in Gilts has been $5.0 \%$ ), including government securities and units of mutual funds (Table 1.6). Thus the fixed income bearing instruments are the most preferred assets of the household sector. 
Table 6 Savings of Household Sector in Financial Assets (in percent)

\begin{tabular}{|c|c|c|c|c|c|c|c|c|c|c|}
\hline Financial Assets & $\begin{array}{l}1995- \\
96\end{array}$ & $\begin{array}{c}1996- \\
97\end{array}$ & $\begin{array}{c}1997- \\
98\end{array}$ & $\begin{array}{c}1998- \\
99\end{array}$ & $\begin{array}{c}1999- \\
00\end{array}$ & $\begin{array}{c}2000- \\
01\end{array}$ & $\begin{array}{c}2001- \\
02\end{array}$ & $\begin{array}{l}2002- \\
03(P)\end{array}$ & $\begin{array}{l}2003- \\
04(P)\end{array}$ & $\begin{array}{c}2004- \\
05 \#\end{array}$ \\
\hline Currency & 13.3 & 8.6 & 7.4 & 10.4 & 8.6 & 6.4 & 9.5 & 8.9 & 10.5 & 9.2 \\
\hline $\begin{array}{l}\text { Fixed income } \\
\text { investments }\end{array}$ & 79.1 & 84.5 & 88.0 & 85.3 & 84.2 & 89.4 & 82.4 & 86.9 & 84.7 & 84.8 \\
\hline Deposits & 42.5 & 48.1 & 46.6 & 39.2 & 39.2 & 44.3 & 37.9 & 40.9 & 41.6 & 39.4 \\
\hline $\begin{array}{c}\text { Insurance/Provident/ } \\
\text { Pension Funds }\end{array}$ & 29.2 & 29.4 & 30.1 & 33.3 & 34.0 & 33.5 & 33.4 & 31.1 & 27.6 & 26.4 \\
\hline Small Savings & 7.4 & 7.0 & 11.3 & 12.8 & 11 & 11.6 & 11.1 & 14.9 & 15.5 & 19.0 \\
\hline Securities Market & 7.7 & 6.9 & 4.5 & 4.2 & 7.3 & 4.3 & 8.0 & 4.2 & 4.8 & 6.1 \\
\hline Mutual Funds & 0.5 & 2.7 & 1.4 & 1.9 & 4.9 & 1.3 & 1.7 & 1.3 & 1.2 & 0.4 \\
\hline Government Securities & 0.4 & 0.4 & 1.6 & 0.6 & 0.9 & 1.6 & 5.7 & 2.5 & 4.7 & 5 \\
\hline Other Securities & 6.8 & 3.8 & 1.5 & 1.7 & 1.5 & 1.4 & 0.6 & 0.4 & -1.1 & 0.7 \\
\hline Total & 100.0 & 100.0 & 100.0 & 100.0 & 100.0 & 100.0 & 100.0 & 100.0 & 100.0 & 100.0 \\
\hline
\end{tabular}

Source: NSE Fact Book 2005 P: Provisional Figures \#: Preliminary Figures

\subsection{Investor Population and Perception}

SEBI in association with the National Council of Applied Economic Research (NCAER) conducted a Survey of Indian Women investors in 1998-99 and then followed it up in 2000-01. The survey of 2000-01 was based on a sample of 288,081 geographically dispersed in both rural and urban areas. The findings of this survey were released in September 2003. The survey estimated that a total of 13.1 million or 7.4 per cent of all Indian households totalling 21 million individuals directly invested in equity shares or debentures or both during 2000-01. The other findings are as listed below:

The number of debentures owning households and individual debenture holders far exceeds household and individual equity women investors. Of the total 13.1 million investor households, 9.6 million households own bonds or debentures, whereas only 6.5 million investor households own equity shares.

The percentage of households investing in equity or debentures is more in urban areas than in rural areas. This divergence is more in the case of equities compared to debentures. Of the 51 million urban households, 7.8 million households represent more than 12 million urban individual women investors own equity shares or debentures or both. Whereas, of the 125 million rural households, only 5.3 million households representing more than 8 million individual women investors show a definite migration of women investors from equity market to bond market during the period between the two surveys.

The survey results also clearly reveal that a number of non-investor households have increased from about 156 million in 1998-99 to nearly 164 million in 2001-02 constituting nearly 92.6 per cent of all households.

It is also observed that the investor population and town size are directly proportional. The largest city with more than 59 lakh population accounts for about 17 per cent of investor households and the next higher segment, i.e. more than 31 per cent investor households are in towns with a population between 10 and 50 lakh (Pratip Kar and et. al. 2000). 


\subsection{Women Investors' Awareness}

Women investors are the backbone of the securities market. An educated and knowledgeable investor is not only well acquired with the functioning of the market, but also is aware of his rights and obligations. As the class of educated women investors increases, so does the width of the market. The regulators, self regulatory organizations (SROs), non-government organisations (NGOs), and investor associations need to take steps to educate the women investors. SEBI launched a comprehensive education campaign aimed at women investors in securities market, which had been christened - "Securities Market Awareness Campaign". The motto of this campaign is "An Educated Investor is a Protected Investor". Following the national launch, the campaign has already been extended to 20 states and Union territories. Approximately, 2,000 workshops spread around 480 cities were held during the fiscal year 2004-05. SEBI has also put in place a comprehensive investor grievances processing mechanism. The Office of Investor Assistance and Education (OIAE) is a single window interface of SEBI. It accepts complaints from aggrieved women investors for matters falling within its jurisdiction. These complaints are acknowledged and taken up with the concerned entities either directly by OIAE or by the Investor Complaint Cell of the concerned department.

The Department of Company Affairs (DCA) also informs the general public about the agency they should approach for redressal of their grievances. For complaints relating to deposits in banking companies and non-banking financial companies, the women investors should approach the Reserve Bank of India (RBI). All complaints relating to listed companies are dealt by SEBI and the unlisted companies by DCA. In the case of deposits from non-banking non-financial companies, the depositors should approach the Company Law Board. If the orders passed by the Board are not honoured, then they should approach the concerned Registrar of Companies. These complaints relate to non-registration of transfer of shares, non-refund of share application money, non-receipt of dividends, non-receipt of duplicate shares, non-issue of share certificates, non-issue of debenture certificates, bonus shares, share certificates on conversion, after endorsement (ISMR, 2005).

\section{INTERNATIONAL SCENARIO}

Following the implementation of reforms in the securities market during the last decade, Indian stock markets have stood out in the world ranking as well as in the developed and emerging markets. As may be seen from table 1.7, India has a turnover ratio of $113.7 \%$, which is quite comparable to the other developed market like the US and UK which have turnover ratios of $126.5 \%$ and $140.5 \%$ respectively. As per the Standard and Poor's Factbook, India ranked 18th in terms of market capitalization (17th in 2003), 18th in terms of total value traded in stock exchanges (16th in 2003) and 15th in terms of turnover ratio (6th in 2003) as on December 2004. India ranked second in terms of the listed securities on the Exchange next to the USA. These data, though quite impressive, do not reflect the full Indian market, as Standard \& Poors (S\&P) even other international publications does not cover the whole market. For example, India has approximately 9000 listed companies at the end of March 2005, while S\&P considers only 4,730 companies. If whole markets were taken into consideration, India's position vis-avis as compared to other countries would be much better.

A comparative study of concentration of market indices and indices stocks in different world markets is presented in Table - 1.8 below. It is seen that the index stocks' share of total market capitalization in India is $73.7 \%$ whereas US index accounts for $92.6 \%$. The ten largest index stocks share of total market capitalization in $33.4 \%$ in India and $14.7 \%$ in the case of US. 
Table 7 International Comparison: End of December 2004

\begin{tabular}{|c|c|c|c|c|c|c|c|c|}
\hline Particulars & USA & UK & Japan & Germany & Singapore & $\begin{array}{c}\text { Hong } \\
\text { kong }\end{array}$ & China & India \\
\hline No. of listed Companies & 5,231 & 2,486 & 3,220 & 660 & 489 & 1,086 & 1,384 & 4,730 \\
\hline $\begin{array}{c}\text { Market Capitalisation } \\
(\$ \text { Bn.) }\end{array}$ & 16,324 & 2,816 & 3,678 & 1,195 & 172 & 861 & 640 & 388 \\
\hline $\begin{array}{c}\text { Market Capitalisation Ratio } \\
(\%)\end{array}$ & 148.2 & 167.6 & 84.3 & 57.3 & 190.1 & 488.8 & 45.2 & 68.0 \\
\hline $\begin{array}{c}\text { Turnover (\$ Bn.) } \\
\text { Turnover Ratio (\%) }\end{array}$ & 19,355 & 3,707 & 3,430 & 1,406 & 81 & 439 & 748 & 379 \\
\hline
\end{tabular}

Source: S\&P Global Stock Markets Factbook, 2005

Table 8 Market Concentration in the World Index as on End 2004 (In Percent)

\begin{tabular}{|c|c|c|}
\hline Market & $\begin{array}{c}\text { Index Stocks Share of } \\
\text { Total Market } \\
\text { Capitalization }\end{array}$ & $\begin{array}{c}\text { 10 largest Index Stocks' } \\
\text { Share of Total Market } \\
\text { Capitalization }\end{array}$ \\
\hline Japan & 97.1 & 18.2 \\
\hline Singapore & 94.6 & 34.2 \\
\hline France & 75.1 & 35.6 \\
\hline Germany & 87.1 & 45.1 \\
\hline Italy & 98.8 & 57.2 \\
\hline United Kingdom & 95.9 & 40.9 \\
\hline United States & 92.6 & 73.7 \\
\hline India & 14.7 & 33.4 \\
\hline
\end{tabular}

Source: S\&P Global Stock Markets Factbook, 2005

The stock markets worldwide have grown in size as well as depth over the last decade. As can be observed from table 1.9, the turnover on all markets taken together have grown from US \$ 37.75 trillion in 2002 to $\$ 39.31$ trillion in 2004, though it witnessed a decline and stood at US $\$ 29.6$ trillion in 2003. It is significant to note that US alone accounted for about $49.24 \%$ of worldwide turnover in 2004. Despite having a large number of companies listed on its stock exchanges, India accounted for a meager $0.96 \%$ in total world turnover in 2004 . The market capitalization of all listed companies taken together on all markets stood at US\$38.90 trillion in 2004 ( $\$ 32.01$ trillion in 2003). The share of US in worldwide market capitalization decreased from $44.54 \%$ as at the end of 2003 to $41.96 \%$ at the end of 2004, while Indian listed companies accounted for $1.00 \%$ of total market capitalization in 2004 .

There has also been an increase in market capitalization as per cent of GDP in some of the major country groups as is evident from table - 1.10. The increase, however, has not been uniform across countries. The market capitalization as per cent of GDP was the highest at 100.1 $\%$ for high-income countries at the end of 2003 and the lowest for low-income countries at $37.3 \%$. Market capitalization as per cent of GDP for India stood at $46.5 \%$ at the end of 2003 . The turnover ratio, which is a measure of liquidity, however is approximately the same for both the high-income countries and low-income countries $110.1 \%$ and $130.5 \%$, respectively. The total number of listed companies stood at 27,594 for high-income countries, 14,456 for middleincome countries and 7,988 for low-income countries as at the end of 2004. 
Table 9 Market Capitalization and Turnover for Major Markets (US \$ million)

\begin{tabular}{|c|c|c|c|c|c|c|}
\hline \multirow{2}{*}{ Country/Region } & \multicolumn{3}{|c|}{$\begin{array}{c}\text { Market Capitalization } \\
\text { (end of period) }\end{array}$} & \multicolumn{3}{c|}{ Turnover } \\
\cline { 2 - 7 } & 2002 & 2003 & 2004 & 2002 & 2003 & 2004 \\
\hline Developed Markets & $21,039,479$ & $28,370,952$ & $34,173,600$ & $35,287,887$ & $26,805,163$ & $35,341,782$ \\
\hline Australia & 378,846 & 585,475 & 776,403 & 294,658 & 369,845 & 514,249 \\
\hline Japan & $2,126,075$ & $3,040,665$ & $3,678,262$ & $1,573,279$ & $2,272,989$ & $3,430,420$ \\
\hline UK & $1,864,262$ & $2,460,064$ & $2,815,928$ & $1,909,716$ & $2,211,533$ & $3,707,191$ \\
\hline USA & $11,098,102$ & $14,266,266$ & $16,323,726$ & $25,371,270$ & $15,547,431$ & $19,354,899$ \\
\hline All Emerging Markets' & $2,419,060$ & $3,656,292$ & $4,730,4-18$ & $2,465,909$ & $2,896,804$ & $3,967,806$ \\
\hline China & 463,080 & 681,204 & 639,765 & 333,369 & 476,813 & 748,274 \\
\hline India & 131,011 & 279,093 & 387,851 & 197,118 & 284,802 & 379,085 \\
\hline Indonesia & 29,991 & 54,659 & 73,251 & 13,042 & 14,774 & 27,561 \\
\hline Korea & 249,639 & 329,616 & 428,649 & 792,165 & 682,706, & 638,891 \\
\hline Malaysia & 123,872 & 168,376 & 190,011 & 27,623 & 50,135 & 59,878 \\
\hline Philippines & 18,549 & 23,565 & 28,948 & 3,103 & 2,635 & 3,664 \\
\hline Taiwan & 261,474 & 379,023 & 441,436 & 631,931 & 592,012 & 718,619 \\
\hline World Total & $23,458,539$ & $32,027,244$ & $38,904,018$ & $37,753,796$ & $29,701,967$ & $39,309,589$ \\
\hline US as \% of World & 47.31 & 44.54 & 41.96 & 67.20 & 52.34 & 49.24 \\
\hline India as\% of World & 0.56 & 0.87 & 1.00 & 0.52 & 0.96 & 0.96 \\
\hline
\end{tabular}

Source: S\&P Global Stock Markets Fact book, 2005

Table 10 Select Stock Market Indicators

\begin{tabular}{|c|c|c|c|c|c|c|c|c|c|}
\hline \multirow{2}{*}{ Markets } & \multicolumn{3}{|c|}{$\begin{array}{c}\text { Market } \\
\text { Capitalization } \\
\text { as \% of GDP }\end{array}$} & \multicolumn{3}{c|}{ Turnover Ratio (\%) } & \multicolumn{3}{c|}{$\begin{array}{c}\text { Listed Domestic } \\
\text { Companies }\end{array}$} \\
\cline { 2 - 11 } & $\mathbf{1 9 9 0}$ & $\mathbf{2 0 0 2}$ & $\mathbf{2 0 0 3}$ & $\mathbf{1 9 9 0}$ & $\mathbf{2 0 0 3}$ & $\mathbf{2 0 0 4}$ & $\mathbf{1 9 9 0}$ & $\mathbf{2 0 0 3}$ & $\mathbf{2 0 0 4}$ \\
\hline High Income & 51.6 & 83.4 & 100.1 & 59.4 & 137.9 & 110.1 & 17,747 & 26,947 & 27,594 \\
\hline Middle Income & 19.4 & 35.3 & 44.5 & 78.3 & 44.1 & 60.9 & 4,231 & 13,307 & 14,456 \\
\hline Low \& Middle Income & 18.8 & 33.3 & 43.5 & 70.7 & 57.8 & 72.4 & 7,677 & 20,629 & 22,444 \\
\hline East Asia \& Pacific & 16.4 & 40.4 & 53.5 & 118.1 & 72.7 & 103.5 & 774 & 3,132 & 3,582 \\
\hline Europe \& Central Asia & 2.2 & 22.7 & 29.7 & -- & 53.6 & 37.9 & 110 & 6,781 & 7,776 \\
\hline $\begin{array}{c}\text { Latin America \& } \\
\text { Caribbean }\end{array}$ & 7.7 & 27.4 & 33.2 & 29.8 & 21.7 & 22.0 & 1,734 & 1,381 & 1,468 \\
\hline $\begin{array}{c}\text { Middle East \& } \\
\text { N. Africa }\end{array}$ & 27.4 & 26.1 & 47.3 & -- & 19.6 & 64.4 & 817 & 1,585 & 1,803 \\
\hline South Asia & 10.8 & 22.7 & $39: 8$ & 54.0 & 180.3 & 131.2 & 3,231 & 6,839 & 6,909 \\
\hline Sub-Saharan Africa & 52.3 & 47.3 & 105.9 & -- & 23.7 & 39.3 & 1,011 & 911 & 906 \\
\hline Low Income & 9.8 & 22.6 & 37.3 & 53.8 & 139.6 & 130.5 & 3,446 & 7,322 & 7,988 \\
\hline India & 12.2 & 25.7 & 46.5 & 65.9 & 14.1 & 115.5 & 2,435 & 5,644 & 4,730 \\
\hline World & 48.0 & 74.6 & 89.7 & 57.2 & 123.0 & 72.4 & 25,424 & 47,576 & 50,038 \\
\hline
\end{tabular}

Source: World Development Indicators 2004, World Bank. 


\section{REGULATIONS IN CAPITAL MARKET}

In India, Capital Issues (Control) Act, 1947 and the Securities Contracts (Regulation) Act, 1932 provided the necessary basic framework for regulation, issue of securities and the functioning of the securities market till 1992. Enforcement of the law was vested with the Government itself. There was no single authority to regulate and administer the laws relating to securities and capital market. This state of affair was unsatisfactory and needed to be reformed with the passage of time and the change in economic philosophy. Comprehensive law and a better enforcement agency were needed. This has resulted in the creation of a Board called Securities and Exchange Board of India (SEBI).

SEBI is vested with powers of Securities Contract (Regulation) for free pricing and issuing rules, regulations and guidelines. SEBI has taken a series of steps to regulate the procedure and performance of capital market. It has given a code of conduct for all its employees including the chairman who bars them from making any direct and indirect investments in equity or equity related instruments.

\subsection{Regulatory Framework}

The four main legislations governing the securities market are (a) the SEBI Act, 1992 (b) the Securities Contract (Regulation) Act, 1956 (c) the Depositories Act, 1996 and (d) the Companies Act, 1956. A brief about these legislations are as given below:

SEBI Act 1992: The SEBI Act 1992, was enacted to empower SEBI with statutory powers for (a) protecting the interests of women investors in securities, (b) promoting the development of the securities market, and (c) regulating the securities market. Its regulatory jurisdiction extends over the corporate in the issuing capital and all intermediaries and persons associated with the securities market. It can conduct enquiries, audits and inspections of all concerned participants and adjudicate offences under this Act. It has powers to register and regulate all the market intermediaries.

Securities Contract (Regulation) Act, (SCRA) 1956: It provides for direct and indirect control of virtually all aspects of the securities trading including the functioning of stock exchanges with an aim to prevent undesirable transactions in securities. It gives the Central Government regulatory jurisdiction over (a) stock exchanges through a process of recognition and continued supervision, (b) contracts in securities and (c) listing securities on stock exchanges. The stock exchanges frame their own listing regulations in consonance with the minimum listing criteria set out in the Rules.

Depositories Act, 1996: The Depositories Act, 1996 provides for the establishment of depositories for securities to ensure transferability of securities with speed, accuracy and security. For this these following provisions have been made: (a) making securities of public limited companies freely transferable subject to certain exceptions (b) dematerializing the securities in the depository mode; (c) Providing for maintenance of ownership records in a book entry form. In order to streamline the settlement process, the Act envisages transfer of ownership of securities electronically by book entry without moving the securities from person to person. The Act has made the securities of all public limited companies freely transferable, restricting the company's right to use discretion in effecting the transfer of securities, and the transfer deed and other procedural requirements under the Companies Act have been dispensed with.

Companies Act 1956: It deals with the issue, allotment and transfer of securities and various aspects relating to company management. It provides for standards of disclosure in the public issues, particularly, in the fields of company management and projects, information about other listed companies under the same management, and management perception of risk factors. It 
also regulates underwriting, the use of premium and discounts on issues, rights and bonus issued, payment of interest and dividends, supply of annual report and other information.

\subsection{Rules, Regulations and Regulators}

The Government has framed rules under the SCRA, the SEBI Act and the depositories Act. The SEBI has framed regulations under these acts for registration and regulation of the market intermediaries and for prevention of unfair trade practices. Under these Acts, the Government and the SEBI issue notifications, guidelines and circulars, which the market participants has to comply with.

Most of the powers under the SCRA are exercisable by Department of Economic Affairs (DEA) while a few others by SEBI. The regulation of the contracts for sale and purchase of securities, gold related securities, money market securities and securities derived from these securities and ready to forward contracts in debt securities are exercised concurrently with the RBI. The SEBI Act and the Depositories Act are mostly administered by SEBI. While the rules under the securities laws are framed by the government, regulations are framed by SEBI. The powers under the Companies Act relating to issue and transfer of securities and nonpayment of dividend are administered by SEBI in the case of listed public companies and public companies proposing to get their securities listed. The Self Regulatory Orgaisations (SROs) ensure compliance of market participants with their own rules as well as the rules relevant to them under the securities law.

\subsection{Reforms in Indian Securities Markets}

Corporate Securities Market: During the last decade, there have been substantial regulatory, structural, institutional and operational changes in the securities industry. These have been carried out with the objective of improving market efficiency, enhancing transparency, preventing unfair trade practices and bringing the Indian market upto international standards. The following paragraphs list the principal reform measures undertaken in the last decade.

Establishment of SEBI: It was set up as an administrative body in April 1988 and was given the statutory status in November 1992 with the promulgation of the SEBI ordinance. Its main objective is to protect the interest of women investors in securities and to promote the development and to regulate the security market. The courts have upheld the powers of SEBI to impose monetary penalties and to levy fees from market intermediaries. In the recent amendment to the SEBI Act, the regulatory has also been given search and seizure powers.

DIP Guidelines: With the repeal of the capital issues (Control) Act, 1947 in May 1992, the Government's control over issue of capital, pricing of the issues, fixing of premium and rates of interest on debentures etc. Thereafter, the market has been allowed to allocate resources among the competing uses. In the interest of investors, SEBI has issued the Disclosure and investors Protection (DIP) guidelines, which contain a slew of requirements for issuer's intermediaries with a broad intention to ensure that all concerned observe high standards of integrity and fair dealings. It also aims to secure fuller disclosure of relevant information about the issuer and the nature of the securities to be issued. This enables the women investors to take informed decisions.

Screen Based Trading: Prior to 1990s, the trading on stock exchanges in India was used to take place through an open outcry system. This system did not allow immediate matching or recording of trades. This was time consuming and imposed limits on trading. In order to provide efficiency, liquidity and transparency, NSE introduced a nation-wide on-line fully automated screen based trading system (SBTS). In this system, a member can punch into the computer quantities of securities and the prices at which he desires to transact and the 
transaction is executed as soon as it finds a matching sale or buy order from a counter party. SBTS electronically matches orders on price/time priority and hence it cuts down on time and cost. It enables market participants to see the full market on real-time, making the market transparent. It allows a large number of participants, irrespective of their geographical locations, to trade with one another simultaneously, improving the depth and liquidity of the market.

Trading Cycle: Initially, the trading cycle varies from 14 days for specified securities to 30 days for others and settlement takes another fortnight. Often this cycle is not adhered to and on several occasions leads to defaults and risks in settlement. In order to reduce large open positions, the trading cycle is reduced over a period of time to a week. The exchanges, however, continue to have different weekly trading cycles, which enable shifting of positions from one exchange to another. Rolling settlement on $\mathrm{T}+5$ basis has been introduced in respect of specified scripts reducing the trading cycle to one day. It is made mandatory for all exchanges to follow a uniform weekly trading cycle in respect of scripts not under rolling settlement. All scripts move to rolling settlement since December 2001. The settlement period has been reduced progressively from $\mathrm{T}+5$ to $\mathrm{T}+2$ days.

Derivatives Trading: To assist market participants to manage risks better through hedging, speculation and arbitrage, SCRA was amended in 1995 to lift the ban on options in securities. However, trading derivatives took off much later after the suitable legal and regulatory framework was out in place. Derivatives trading commenced in June 2000 in the Indian securities market on NSE and BSE only. The market presently offers index futures and index options on three indices and stock options and stock futures on individual stocks and futures in interest rate products like notional 91-day T-Bills and notional 10-year bonds.

Demutulisations: Historically, brokers owned, controlled and managed the stock exchanges. In case of disputes, integrity of the exchange suffered. Therefore regulators focussed on reducing the dominance of trading members in the management of stock exchanges. They advised them to reconstitute their governing councils to provide for at least $50 \%$ non-broker representation. However, this did not materialize and alter the situation. In face of extreme volatality in the securities market in 2000 , the Government proposed to corporatise the stock exchanges by which ownership, management and trading membership would be segregated from one another. A few exchanges have already initiated demutualisation process. NSE, however, has adopted a pure demutualised governance structure where ownership, management and trading are with three different sets of people. This completely eliminates any conflict of interest and helps NSE to aggressively pursue policies.

Depositories Act: The earlier settlement system gave rise to settlement risk. This was due to the time taken for settlement and due to the physical movement of paper. Further, the transfer of shares in favour of the purchaser by the company also consumed considerable amount of time. To obviate these problems, the Depositories Act 1996 was passed to provide for the establishment of depositors in securities. The objective was to ensure free transferability of securities with speed and accuracy. This act brought in changes by (a) making securities of public limited companies freely transferable subject to certain exceptions; (b) dematerializing of securities in the depository mode; and (c) providing for maintenance of ownership records in a book entry form. In order to promote dematerialization, the regulatory has been promoting settlement in demat form in a phased manner in an ever-increasing number of securities. The stamp duty on transfer of demat securities has been waived. There are two depositories in India Viz. NSDL and CDSL. They have been set up to provide instantaneous electronic transfer of securities. 
To prevent physical certificates from sneaking into circulation, it has been mandatory that all new securities issued should be compulsorily traded in a dematerialized form. The admission to a depository for dematerialization of securities has been made a prerequisite for making public or rights issue or an offer for sale. It has also been made compulsory for public listed companies making IPO of any securities for Rs.10 crore or more only in dematerialized form.

Risk Management: With a view to avoid any kind of market failures, the regulator/exchanges have developed a comprehensive risk management system, which is constantly monitored and upgraded. It encompasses capital adequacy of members, adequate margin requirements, limits on exposure and turnover, indemnity insurance, on-line position monitoring and automatic disablement, etc. They also administer an efficient market surveillance system to detect and prevent price manipulations. The clearing corporation has also put in place a system which tracks online real time client level portfolio based upfront margining. Exchanges have set up trade/settlement guarantee funds for meeting shortages arising out of non-fulfillment/partial fulfillment of funds obligations by the members in a settlement. As a part of a risk management system, index based market wide circuit breakers have also been put in place.. The National Securities Clearing Corporation Ltd. (NSCCL), which commenced its operations in April 1996, assured the counter party risk of each member and guaranteed financial settlement. It established a Settlement Guarantee Fund (SGF). The SGF provides a cushion for any residual risk and operates like a self-insurance mechanism wherein members contribute to the Fund. In the event of failure of a trading member to meet his obligations, the fund is utilized to the extent required for successful completion of the settlement. This has eliminated counter-party risk in trading on the Exchanges.

Investor Protection: As already mentioned the SEBI Act established SEBI with the primary objective of protecting the interests of women investors in securities and empowers it to achieve this objective. SEBI specifies that critical data should be disclosed in the specified formats regarding all the concerned market participants. The Central Government established a fund called Investor Education and Protection Fund (IEPF) in October 2001 for the promotion of awareness amongst women investors and protection of the interest of women investors.

DEA, DCA, the SEBI and the stock exchanges have set up investor grievance cells for redressal of investor grievance. The exchanges maintain investor protection funds to take care of investor claims. The DCA has also set up an investor education and protection fund for the promotion of women investors' awareness and protection of interest of women investors. All these agencies and investor associations organise investor education and awareness programmes. In January 2003, SEBI launched a nation-wide Securities Market Awareness Campaign that aimed at educating women investors about the risks associated with the market as well as the rights and obligations of women investors. The NSE have also taken special measures for educating the women investors; it conducts seminars, workshops and comes out with advertisement both in print and electronic media to communicate to the women investors.

Globalization: Indian securities market is getting increasingly integrated with the rest of the world. Indian companies have been permitted to raise resources from abroad through issue of ADRs (American Depository Receipts), GDRs (Global Depository Receipts), FCCBs (Foreign Currency Convertible Bonds) and ECBs (External Commercial Bodies). Further, foreign companies are allowed to tap the domestic stock market. Indian companies are permitted to list their securities on foreign stock exchanges by sponsoring ADR/GDR issued against block shareholdings. FIIs (Foreign Institutional Women investors) have been permitted to invest in all types of securities, including government securities. The investments by FIIs enjoy full capital account convertibility. They can invest in a company under portfolio investment route upto $24 \%$ of the paid-up capital of the company, which can be increased up to the sectrol 
cap/statutory ceiling, as applicable. The Indian stock exchanges have been permitted to set up trading terminals abroad. The trading platform of Indian exchanges is accessed through the Internet from anywhere in the world.

The two-way fundability for ADRs/GDRs has been permitted by RBI, which means that the women investors in any company that has issued ADRs/GDRs could freely convert them to ADRs/GDRs into underlying domestic shares. They could also reconvert the domestic shares into ADRs/GDRs, depending on the direction of price change in the stock. This is expected to bring an improvement in the liquidity in ADR/GDR market and elimination of arbitrage opportunity. This will better align ADR/GDR prices and domestic share prices of companies that have floated ADRs/GDRs.

\subsection{Objectives of Entering the Capital Market}

Funds can be raised through issue of equity shares at a premium or at par, or at a discount, issue of bonus shares, issue of debentures and bonds, issue of rights shares and debentures, issue of bonds by public sector undertakings and issue of units by mutual funds in the capital market. Companies may enter the capital market to raise money for - setting up new projects, expenditure on diversification of existing project, normal capital expenditure for modernization merger/amalgamation of companies, capital restructuring, acquisition of assets/takeovers, augmenting long-term resources for working capital requirements and the listing of securities.

\subsection{Instruments in Debt Market}

Alike equity market, there is a market for debt instruments, which implies instruments floated or issued by companies, institutions or banks which are debt to the issuer and are repayable to the contributor of debt along with consideration in the form of interest or premium on repayment/redemption of security and consistency in returns. Such debt instruments may be Government bonds - Fixed rate or floating rate bonds, PSU bonds, Certificates of deposits, Debentures, Pension bonds, Tax free bonds, Certificates (rural bonds, kisan vikas patras, etc.) company deposits, structured obligations, securitised instruments, gilts, The kind of return a debt instrument will generate depends upon the choice of instruments. The return is inversely proportional to the safety of the instrument. Return is high in case of risk instrument. The investor has to strike a balance between the risk profile of the instrument and his expectation of the return.

\subsection{New Instruments}

New instruments have been introduced in the light of on-going liberalization and deregulation of capital markets. These instruments have been used by companies and financial institutions in recent past as a tool of raising funds from the capital market - commercial paper, zero interest bonds and debentures, deep discount bonds and other long-term bonds, option bonds, cumulative convertible preference shares, debentures with equity and tradable warrants, secured premium notes (SPN), Euro convertible bonds (ECB), flexi bonds, money market instruments, debt/gilt edged securities, mutual fund unit - open ended and close ended, time share investments and collective investment schemes. Due to the different requirements of the companies and the women investors, aforesaid instruments have been tried out in Indian capital market.

\subsection{Shares}

The capital of the company is divided into different units with definite values and the units are called shares. a person who holds shares is called a shareholder. Shares are represented by share certificates, issued under the common seal of the company specifying the shares held by 
such a member and the certificate is the evidence of their title to such shares. There are two types of shares, namely, (i) Preference shares and (ii) Equity shares.

\subsubsection{Preference Shares}

Preference share capital is a mixed form of financing which has features of equity as well as debt. It resembles a debt because rate of preference dividend is fixed. Preference has a preferential right as (a) to receive the dividend during the life time of the company and (b) to repayment of capital on the winding up. Preference shares can be cumulative or non-cumulative, participating or non-participating, convertible or non-convertible and redeemable or irredeemable.

\subsubsection{Equity Shares}

Equity shares are those shares which are not preferred shares. They are also called ordinary shares. The holders of these shares are entitled to receive the dividend or share in the property after the preference share holders are paid.

Equity share capital is the contribution made by the owners who bear the risk of ownership and are rewarded by way of profits or dividend. Equity share capital can be raised through promoters contribution or public issue of shares or through over the counter exchange of India in case of small issues or placing the shares through mutual funds or rights issues.

\subsection{Debentures}

Debenture has not been defined in the Companies Act but debenture includes debenture stock, bonds and any other securities of a company, whether constituting a charge on the assets of a company or not. They are the instruments used for raising long-term debt capital. Thus a debenture is a document issued by the company under the company seal acknowledging the debit by it to its holders. Debentures can be of various types - secured and unsecured debentures, full convertible, partly convertible and non-convertible debentures, redeemable and irredeemable debentures, bearer debenture-transferable by delivery, naked debentures - do not carry any charge on assets, mortgage debentures- secured by mortgage on the assets of a company.

\subsection{Mutual Funds}

A mutual fund is a special type of investment institution, which acts as an investment conduit. It pools the funds of the women investors and invests the same into well-diversified portfolios. It employs fund managers and investment consultants for maximizing returns on investments. These institutions are popularly known as mutual funds.

\subsubsection{Background of Mutual Fund}

Mutual funds are generally used for open-ended investment schemes being set up by banks or financial and other institutions, which raise funds from the public through issue of stocks or units. Holders are assured of a fixed percentage of return on their investment. The units so issued are also eligible for redemption at a later date. The funds collected are invested in stock exchange securities or money market operations.

\subsubsection{Mutual Fund - A Globally Proven Investment}

Worldwide, the mutual fund, or unit trust as it is called in some parts of the world, has a long and successful history. The popularity of the mutual fund has increased manifold. In developed financial markets, like the United States, mutual funds have almost overtaken bank deposits and total assets of insurance funds. In the United States alone, there are over 5,000 Mutual 
funds with total assets of over US\$ 7000 billion. A mutual fund is formed by the coming together of a number of women investors who handover their surplus funds to a professional organization to manage their funds. A mutual fund is basically a risk diversification tool.

There are various types of mutual funds with different schemes in the finance or capital market and they can be equity fund, growth fund, income fund, real estate funds, off-shore funds, open-ended schemes, close-ended schemes, leverage fund, hedge funds, growth and income funds, specialty fund, asset allocation funds, international funds, tax-exempt fund, dual purpose fund, funds of funds, indexed funds and new direction funds.

\section{CAPITAL MARKET REFORMS}

In 1991-92, securities scam prompted the Government to increase the pace of reforms in the capital market. Several reform measures were initiated since then in both primary and secondary markets. Primary capital market reforms relate to entry norms for capital issues, intermediaries in the primary market and their regulations. Secondary capital market reforms relate to on-line trading, introduction of rolling system, insider trading regulations and so on.

\subsection{Primary Capital Market Reforms}

As already stated, the Securities and Exchange Board of India was set up in 1988 as a nonstatutory body under an administrative arrangement. It was given statutory powers in January 1992 through the enactment of the SEBI Act, 1992 for regulating the securities market. The two objectives mandated in the SEBI Act are investor protection and orderly development of the capital market. The Capital Issues (Control) Act, 1947 was repealed in May 1992, allowing issuers of securities to raise capital from the market without the consent of any authority either for floating an issue or pricing it. Restriction on right and bonus issues was also removed. The interest rate on the debentures was made liberal. However, the new issues are required to meet the SEBI guidelines for Disclosure and Women investors Protection (DIP), which are being strengthened from time to time to protect women investors' interest.

The intermediaries of the primary capital market has been fairly diversified over the years with the setting up of a large number of merchant bankers, investment and consulting agencies, registrars to the issues and so on. The primary capital market has widened and deepened with public sector banks, financial institutions, public sector enterprises with regard to raising resources from the market both by way of debt and equity.

One of the significant steps towards integrating the Indian Capital Market with the international capital markets is the permission given to Foreign Institutional Women investors (FIIs) such as mutual funds, pension funds and country funds, to operate in the Indian market. Foreign Institutional Women investors are initially allowed to invest only in equity shares, later they have been permitted to invest in the debt market, including dated government securities and treasury bills. The investment by Foreign Institutional Women investors increased by 40 per cent in 2000-01 (Bharathi V.Pathak, 2004). This increase could be made with the approval of shareholders through a special resolution in the general body meeting.

The entry norms for Initial Public Offers (IPOs) have been tightened by modifying the Disclosure and Investor Protection (DIP) guidelines. According to the new guidelines, IPOs five times the size of the pre-issue networth are allowed only if the company has a record of profitability and a networth of Rs. 1 crore in any three years in the past 15 years. Companies without such a track record or an issue size beyond five times the pre issue are to be allotted to Qualified Institutional Buyers (QIBs). For shares issued to any person by listing companies and verified on a preferential basis, a lock-in period of one year has been stipulated. Infrastructure companies are exempted from the requirement of eligibility norms if the project has been appraised by a public financial institution and not less than 5 per cent of the project 
cost is being financed by any of the institutions jointly or severally, by way of loans and subscriptions to equity (Bharathi V. Pathak, 2004).

\subsection{Secondary Market Reforms}

The open outcry trading system, prevalent till 1995, was replaced by the on-line screen based electronic trading. All stock exchanges had approximately more than 10,000, trading terminals spread over the country. To enhance the level of investor protection, the process of dematerialization of securities through depository system and their transfer through electronic book entry was pursued vigorously. To enable this, the National Securities Depository Limited (NSDL) was set up in November 1996 and the Central Depository Service India Limited (CDSL) in February 1999 (Bharathi V. Pathak, 2004). All actively traded securities are held, traded, and settled in the demat form.

Issuing companies are required to make continuing disclosures under the listing agreement. All listed companies are required to furnish to stock exchanges and also publish un-audited financial statements on a quarterly basis. Disclosure of material information, which may have a bearing on the performance of a company, is also required to be made available to the public. One of the most significant reforms in the secondary market aims at improving corporate governance. Corporate governance is a set of systems and processes designed to protect the interests of stakeholders. It is for creating and enhancing shareholder's wealth while protecting the interests of all other stakeholders. SEBI has appointed a committee under the chairmanship of Kumara Mangalam Birla on corporate governance in India. The committee has framed the codes for corporate governance and suggested implementation of the code through stock exchanges. To ensure greater market transparency, SEBI banned the negotiated and cross deals, all private off-market deals both shares as well as listed corporate debts during the year 1999 . So, these deals are channelised only through trading screens (Bharathi V. Pathak, 2004).

It could be noticed that in the recent past a lot of changes have taken place with regard to the economic policy of the Government and the Corporate Sector: Free pricing, Invitation to foreign institutional investors to make investment in the corporate sector, Direct Foreign Investment in industries, emergence of new institutions and financial instruments. As a result of these developments, there is more possibility for increasing the investment by the women investors. So, this study is focused on analyzing the implications of financial sector reforms in capital market and the influence of the latest developments on the behaviour of women investors.

\section{CONCLUSIONS}

The scope of the study has been limited to certain important aspects of women investors like information search, evaluation of capital market reforms, and preferences in investments. The study restricts the statements regarding capital market reforms and the latest developments in capital market since 1991. Though many reforms are present in Indian Capital Market, the most popular reforms are identified and taken for the study. Though the study is on the implications of financial sector reforms, the main concentration would be on the measures which safeguard the interest of the women investors in the present context of the capital market. This study, thus, focuses mainly on the implications of financial sector reforms and their impact on Indian Capital Market. 


\section{REFERENCES}

[1] Duguid, Charles, The Stock Exchange (1904)

[2] Wadia, P.P. \& Joshi, G. N., Money Market in India (1926)

[3] Thomas, P. J., The Growth of Federal Finance in India (1939)

[4] Place, Siddons \& Gouch, The Investor's India Year Book (1951)

[5] Parekh, H. T., The Bombay Money Market (1953)

[6] Simha, S.L.N., The Capital Market of India (Vora \& Co., Publishers Pvt. Ltd., Bombay, 1960).

[7] Story of Indian Stock Exchange (The Stock Exchange, Bombay, 1968)

[8] Murugesan R, 2016, A study on salaried womens attitude towards investment decisions with reference to namakkal district tamilnadu india 